\title{
PERANG RIDDAH DAN FUTUHAT ISLAMIYAH (KAJIAN RELASI PERISTIWA SOSIAL DAN PERKEMBANGAN BAHASA ARAB)
}

\author{
Wildana Wargadinata \\ Universitas Islam Negeri Maulana Malim Ibrahim Malang, Indonesia \\ Email: wildana@bsa.uin-malang.ac.id \\ Iffat Maimunah \\ Universitas Islam Negeri Maulana Malim Ibrahim Malang, Indonesia \\ Email: iffatmaimunah@uin-malang.ac.id \\ Saidna Zulfiqar Bin Tahir \\ Universitas Iqra Buru \\ saidnazulfiqar@gmail.com
}

\begin{abstract}
Lahirnya agama Islam dan peristiwa-peristiwa sosial yang mengiringinya merupakan fenomena sosial yang mencengangkan sepanjang sejarah abad pertengahan. Islam yang lahir di tempat gersang yang dihuni bangsa primitif telah melahirkan peradaban dunia yang mempesona. Setiap peristiwa sosial yang terjadi di awal lahirnya Islam merupakan peristiwa yang memiliki pengaruh dahsyat terhadap proses revolusi perkembangan bahasa Arab. Bahasa Arab telah menjadi salah satu sumber pengetahuan sehingga upaya untuk mengetahui proses perkembangannya menjadi kebutuhan yang sangat esensial untuk melacak asal muasal terbentuknya bahasa tersebut dan faktor faktor yang menjadikan bahasa Arab sebagai bahasa terdepan di era ini. Tulisan ini memperlihatkan bahwa peristiwa sosial yang mengiringi lahirnya agama Islam membawa dampak dan pengaruh pada perkembangan bahasa Arab, hal ini menunjukkan bahwa perkembangan bahasa Arab tidak hanya dipengaruhi dari peradaban yang berkembang sebelum lahirnya Islam. Sebagaimana ditunjukkan dalam tulisan ini bahwa peristiwaperistiwa sosial pada masa shadr Islam merupakan transformasi proses perkembangan bahasa Arab. Pada masa itu merupakan momentum agung turunnya al-Qur'an. Masuknya ajaran agama Islam kepada masyarakat jahiliah Arab membangun hubungan interaksi sosial masyarakat Arab dan Islam. Pada masa ini terjadi proses pertumbuhan ilmu pengetahuan yang bersumber dari Islam, yang berdampak nyata pada perkembangan bahasa Arab. Tulisan ini menyarankan perlunya suatu kajian lebih lanjut atas perkembangan bahasa Arab yang dibangun dari aspek historis. Mengingat sejarah panjang dalam Islam, menegaskan adanya momentum agung yang mampu mengembangkan bahasa Arab sebagai bahasa istimewa bagi umat Islam dan peradaban dunia.
\end{abstract}

Keywords: Futuhat Islamiyah, Relasi Peristiwa Sosial, Perkembangan Bahasa Arab

\section{INTRODUCTION}

Peristiwa sosial yang mengiringi lahirnya agama Islam merupakan peristiwa sosial yang mencengangkan sepanjang sejarah. Kelahiran Islam dari sebuah tempat yang gersang, tempat hunian bangsa primitif, tempat yang tidak memiliki infra struktur telah mampu melahirkan peradaban yang benar-benar sangat mempesona (Teebi, 2010). Peristiwa sosial termasuk di dalamnya peperangan yang terjadi di awal lahirnya Islam merupakan peristiwa pelik yang ternyata memberikan pengaruh pada peristiwa lain yang sangat dahsyat pula (Firestone, 2002), yaitu peristiwa bahasa (revolusi perkembangan bahasa). Peristiwa ini pula yang mengantarkan bahasa Arab dari bahasa lokal (kabilah) lalu berkembang menjadi bahasa peradaban yang mendunia. Perkembangan Islam yang 
diiringi dengan tradisi dan ajaran baru mengajarkan kepatuhan dan ketundukan kepada Allah, di samping perubahan menuju nilai-nilai keislaman juga ditekankan. Perubahan ajaran yang cukup radikal ini mengharuskan adanya perubahan radikal dalam tradisi bangsa Arab yang membutuhkan bahasa sebagai media untuk menumbuhkembangkannya (Dajani, 2015). Bahasa Arab sebagai bahasa umat Islam pada awal kemunculannya, belum memiliki kosakata yang memadai, dan belum mengakomodir perkembangan peradaban baru Islam (Procházka, 2006). Namun seiring dengan perkembangan Islam, ternyata bahasa Arab juga mengalami perkembangan yang sangat signifikan, yang tentunya juga tidak lepas dari adanya peristiwa sosial yang terjadi pada masa Perang Riddah dan Futuhat al-Islamiyah. Perang Riddah dan Futuhat al-Islamiyah ini merupakan peristiwa penting bagi umat Islam yang menjadi starting poin pertumbuhan dan kemajuan Islam di masa awal sejarahnya (Wickens, 1974). Seiring dengan penyampaian ajaran Islam ini maka pengkayaan kosakata baru Bahasa Arab terjadi. Ketika ajaran Islam disampaikan maka bahasapun diucapkan.

Sejauh ini, riset tentang perkembangan bahasa Arab cenderung bertumpu pada tiga pokok pembicaraan. Pertama, perkembangan bahasa Arab diduga sangat sulit dilacak karena bahasa ini merupakan bahasa yang sangat tua. Bahasa Arab merupakan temuan dari prasasti tentang Arab Baidah yang diperkirakan hidup pada abad pertama sebelum masehi (Salim, 2017), kedua, bahasa Arab merupakan bahasa yang memperoleh garansi dan "proteksi ilahi" dan menjadi bagian yang tidak dapat dipisahkan dalam sejarah perkembangan dunia Islam. Bahasa Arab dianggap sebagai bahasa yang paling banyak menyandang atribut, yang sering disebut sebagai bahasa agama dan umat Islam, bahasa dhad (lughah ad-dhâd), bahasa warisan sosial dan budaya (lughah at-turâts). (Buhori \& Wahidah, 2017). Ketiga, sebagai bahasa agama dan umat Islam maka perkembangan Bahasa Arab pada masa dinasti Umayyah berorientasi pada pendalaman agama Islam sebagai motivasi beragama dan pendalaman syair-syair Arab melalui disiplin ilmu Nahwu (Permana, 2018). Dari ketiga kecenderungan tersebut tidak ada perhatian yang diberikan pada hubungan perkembangan Bahasa Arab dengan peristiwa sosial.

Tujuan tulisan ini melengkapi kekurangan dari studi yang ada, yang cenderung menempatkan perkembangan bahasa Arab secara simplisit, dan mengabaikan kompleksitas peristiwa sosial yang mampu mempengaruhi perkembangan bahasa Arab. Sejalan dengan itu, tulisan ini mencoba menggali lebih dalam lagi tentang perkembangan bahasa Arab dan hubungannya dengan peristiwa sosial yang terjadi pada masa shadr Islam, berdasarkan tiga pertanyaan sebagai berikut: (a) peristiwa sosial apa saja yang terjadi pada masa shadr Islam yang berdampak pada perkembangan bahasa Arab? (b) faktor-faktor apa yang mempengaruhi perkembangan Bahasa Arab? (c) bagaimana model perkembangan bahasa Arab yang terbentuk dari peristiwa sosial pada masa shadr Islam?.

Tulisan ini didasarkan pada argumen bahwa (a) perkembangan bahasa Arab tidak hanya dipengaruhi oleh peradaban yang berkembang pada masa jahiliyah, (b) perkembangan bahasa Arab dipengaruhi oleh peristiwa sosial yang terjadi pada masa Shadr Islam, dan (c) peristiwa sosial yang terjadi pada masa Shadr Islam berdampak pada perkembangan Bahasa Arab. Dengan kata lain, peristiwa sosial yang terjadi pada masa shadr Islam memberikan dampak yang sangat signifikan atas perkembangan bahasa Arab yang terus berkembang hingga saat sekarang.

\section{LITERATURE REVIEW}

\subsection{Arab in History and Culture}

Kata jazirah dalam bahasa Arab berarti pulau, istilah jazirah seringkali dipadukan dengan kata Arab, sehingga "Jazirah Arab" memiliki arti "Pulau Arab" (Kemdikbud, 
2016). Dalam sejarah (Hitti, 1970) disebutkan bahwa bangsa Arab menyebut tanah air mereka dengan sebutan jazirah, kendatipun hanya tiga jurusan saja yang dibatasi oleh laut, senada dengan hal itu, sebagian ahli sejarah juga menyebut tanah Arab dengan istilah "Shibhul Jazirah", dalam bahasa Indonesia berarti "Semenanjung". Sedangkan menurut catatan geografi (Teebi, 2010), Jazirah Arab itu berbentuk empat persegi panjang, yang sisi-sisinya tiada sejajar. Di sebelah barat berbatasan dengan Laut Merah, di sebelah selatan dengan Lautan Hindia, di sebelah timur dengan Teluk Arab (dahulu namanya Teluk Persia) dan di sebelah utara dengan Gurun Irak dan Gurun Syam (Gurun Siria). Panjangnya 1000 km lebih, dan lebarnya kira-kira 1000 km (Hitti, 1970).

Berdasarkan wilayahnya, Jazirah Arabia merupakan padang pasir yang terletak di bagian barat daya Asia. Ia merupakan padang pasir terluas dan tergersang di dunia. Luas wilayahnya 120.000 mil persegi, merupakan wilayah strategis dalam peta dunia zaman kuno, ketika benua Australia dan Amerika belum dikenal orang, karena letaknya berada pada posisi pertemuan ketiga benua: Asia, Eropa dan Afrika. Wilayah bagian utara, Arabia berbatasan dengan lembah gurun Syria, sebelah timur berbatasan dengan dataran tinggi Persia, sedangkan bagian barat berbatasan dengan laut Merah. Karena dikelilingi laut pada ketiga sisinya, maka wilayah ini dikenal sebagai "Jazirah Arabia" atau disebut dengan kepulauan Arabia (Teebi, 2010; Calverley \& Hitti., 1943).

Di kepulauan Arabia ini agama Islam muncul pada abad pertengahan. Para sosiolog menganggap peristiwa kelahiran Islam merupakan peristiwa sosial yang paling mencengangkan sepanjang sejarah. Mengingat Islam lahir dari sebuah tempat yang gersang, yang tidak memiliki infra struktur untuk lahirnya sebuah peradaban dan dihuni oleh bangsa primitif yang tidak pernah akan mengukir peradaban dunia, dan Islam hadir sedemikian mempesona (Kirk, 1951). Sebagaimana sejarawan Barat Will Durant (1994) menggambarkan dalam bukunya "The Story of Civilization" dengan pernyataan sebagai berikut:

"Gustinian, tuan Imperium Besar, mangkat pada tahun 565 M, yang kemudian disusul dengan kelahiran Muhammad, lima tahun sesudahnya. Dia dari keluarga fakir pada suatu daerah yang tiga perempatnya berupa padang pasir kerontang dan kurang dihuni oleh banyak penduduk. Mereka itu adalah kabilah-kabilah Badui yang suka berpindah-pindah, apabila dikumpulkan kekayaannya tidak cukup untuk membangun gereja Aya Sofia. Dan tidak ada seorang pun pada waktu itu yang bermimpi bahwa tidak sampai satu abad, orang-orang Badui itu mampu membebaskan separuh kekuasaan Bizantium di Asia, seluruh daerah kekuasaan Persia, Mesir, bagian besar Afrika Utara, dan mulai mengembangkan sayapnya ke Spanyol....Sungguh kejadian itu merupakan gejala sosial yang paling menakjubkan dalam abad-abad pertengahan" (Durant, 1994).

Tidak ada yang menyangka bahwa peristiwa sosial kelahiran Islam ini ternyata menyebabkan peristiwa berikutnya dan tidak kalah dahsyatnya yaitu peristiwa bahasa (revolusi perkembangan bahasa) yang terjadi bersamaan dengan peristiwa Arab exploition. Bersamaan dengan peristiwa-peristiwa sosial dalam sejarah awal perkembangan Islam, berkembang pula revolusi bahasa Arab, yang mengantarkan bahasa Arab dari bahasa lokal atau bahasa kabilah lalu berkembang menjadi bahasa peradaban yang mendunia.

Lahirnya peradaban Islam menunjukkan adanya perbedaan yang mencolok antara periode jahiliyah dengan periode Islam itu sendiri (Halilović, 2017). Sebagaimana catatan sejarah telah menyebutkan bahwa peradaban Islam yang lahir bersama dengan kedatangan Nabi Muhammad SAW. (Wekke, Tamimi, \& Sugandi, 2018), datang di tengah-tengah bangsa Arab benar-benar menjadi ujian terberat bagi bangsa Quraisy dan bangsa Arab pada umumnya. Ajaran yang dibawa Muhammad SAW. benar-benar bertolak belakang dengan ajaran dan tradisi hidup mereka sehari-hari (Tamimi, 2018). Ajaran Islam tidak 
hanya memporak-porandakan ajaran dan tradisi Arab bahkan membaliknya hingga 180 derajat, menyerang tradisi jahiliyah dan membangun tata sosial yang sangat asing bagi tradisi dan rasionalitas Arab sebelumnya (Dabashi, 2017; Dzulhadi, 2015). Keberanian, kepahlawanan dan kedermawanan yang berlebih-lebihan bahkan menjurus kepada kehancuran, loyalitas buta kepada kabilah, kekejian dalam balas dendam, baik dengan perkataan maupun dengan perbuatan merupakan tindakan yang sangat terpuji pada zaman jahiliyah. Sementara Islam datang dengan tradisi dan ajaran baru yang sebaliknya. Islam menjadikan kepatuhan dan ketundukan kepada Allah sebagai dasar dan contoh ajaran yang tertinggi, demikian pula Islam mengajarkan kesabaran, qana'ah dan rendah hati dan menghindari kemewahan yang berlebih-lebihan serta kesombongan (Tamimi, 2018).

Nabi Muhammad SAW. hadir di hadapan bangsa Arab tidak hanya melakukan sebuah perubahan sosial, lebih dari itu perubahan ini merupakan revolusi sosial yang dibawa oleh Nabi (Faesol, 2011). Revolusi yang lahir karena menjadi keharusan, keharusan yang lahir karena perbedaan ajaran yang sangat bertolak belakang. Dari segi nama saja al-Qur'an memberi nama agama baru dengan Islam dan memberi nama untuk masa sebelumnya dengan Jahiliyyah. Kedua penamaan itu nampak perbedaan yang sangat mencolok antara keduanya dari segi corak hidup, rasionalitas dalam prinsip dan tujuannya (Friedmann, 2003). Kata al-jahlu berarti kejam, keras kepala, sombong, bebel dan tidak mau menerima kebenaran (Romziana, 2015). Sebaliknya Islam berarti kedamaian, tepo sliro, toleran dan patuh kepada kebenaran (Ahmad \& Azzam, 2010). Perubahan ajaran yang demikian meniscayakan perubahan pada adat dan tradisi bagi kalangan bangsa Arab. Perubahan ajaran yang cukup radikal ini logikanya juga mengharuskan adanya perubahan radikal dalam tradisi bangsa Arab, yang akhirnya mengantarkan kepada perubahan dari tradisi primitif kepada tradisi baru, sehingga peradaban baru Islam membutuhkan bahasa sebagai media untuk menumbuhkembangkan peradaban Islam di kalangan bangsa Arab.

\subsection{Peristiwa Sosial dan Perkembangan Bahasa Arab}

Bahasa Arab merupakan bahasa warisan yang menonjol (Fishman, 2001; Van Deusen-Scholl, 2003, Temples, 2013) yang memiliki fungsi sebagai budaya dan kekuatan yang mengikat bagi keluarga dan masyarakat Arab. Mengutip dari Muhbib (2014) Bahasa Arab memiliki peran penting dalam memajukan ilmu pengetahuan dan peradaban Islam yang dikaji melalui studi pustaka tentang sejarah bahasa Arab sejak lama. Sejalan dengan hal itu Bahasa Arab merupakan bahasa suci, digunakan untuk tujuan agama, tujuan intelektual dan hukum (Mazraani, 2013). Sehingga, Muhbib (2014) menegaskan lima peran penting Bahasa Arab yaitu; pertama, Bahasa Arab berfungsi sebagai bahasa persatuan di antara orang-orang dan suku-suku Arab. Kedua, bahasa Arab menjaga kekayaan budaya Arab lokal sepanjang waktu. Ketiga, bahasa Arab digunakan sebagai media untuk pendidikan dan studi ilmiah, menjadikannya sebagai bahasa sains dan teknologi. Keempat, bahasa Arab adalah sebagai alat komunikasi di antara orang-orang dan suku-suku dan generasi. Kelima, bahasa Arab diterima sebagai bahasa standar untuk pengetahuan Islam dan ilmu-ilmu modern.

Kelahiran Bahasa Arab bermula di Jazirah Arab (Mu'izzuddin, 2007). Bahasa Arab ini terus tumbuh dan berkembang sebagai hasil proses berpikir dan berbudaya mengiringi proses perkembangan pemikiran dan kebudayaan manusia, sehingga bahasa Arab senantiasa mengalami perkembangan dari waktu ke waktu. Sejalan dengan hal itu, Ali menyatakan bahwa sebelum kelahiran Islam, bangsa Arab terbagi menjadi beberapa suku (Ali, 1995). Tradisi Kesukuan (Tribalisme) yang terdapat pada bangsa Arab ini menimbulkan lahirnya bermacam-macam lahjah (dialek) yang dimiliki oleh setiap suku (Wildana \& Fitriani, 2008), dialek antara satu suku berbeda dengan dialek suku lainnya, 
baik dalam aspek suara, makna, kaidah, maupun dalam kosakata (Wafi, 1945: 108; alTawwab, 1985: 167; Suaidi, 2008). Di antara dialek yang ada, dialek Quraisy merupakan dialek yang mampu mengalahkan dan menguasai dialek-dialek lainnya, dan kemudian jadilah ia bahasa sastra dalam puisi dan prosa semua suku-suku bangsa Arab; ia juga menjadi bahasa agama, bahasa politik dan juga ekonomi (Wafi, 1945: 108; Mu'izzuddin, 2007). Kedudukan dialek Quraisy ini menjadi semakin kokoh sejak turunnya Al-Qur'an yang dibawa oleh Nabi Muhammad SAW. dan Nabi sendiri berasal dari suku Quraisy. Sehingga dialek Quraisy menjadi semakin berkembang seiring meningkatnya intensitas interaksi masyarakat Arab dari berbagai kabilah melalui pasar-pasar mereka yang sekaligus dijadikan pasar festival seni dan sastra, seperti pasar Ukadz, Majannah, Marbad, Dzulmajaz dan Khaibar merupakan pasar yang sangat terkenal sebagai ajang unjuk kebolehan para sastrawan dalam bidang puisi dan pidato (Tohe, 2005).

Sejalan dengan itu, Irwan menegaskan bahwa bahasa sangat terikat pada bagaimana pendukungnya menempatkan bahasa pada posisi tertentu sehingga kondisi/karakter pendukung menentukan bagaimana perkembangan bahasa itu terjadi (Irwan, 2006). Dalam hal ini, dialek Quraisy memiliki faktor pendukung yang mengantarkannya menjadi dialek yang paling dominan di jazirah. Pertama, faktor agama, suku Quraisy adalah penguasa kota Mekah yang di dalamnya terdapat ka'bah yang dikelilingi oleh tuhan-tuhan kabilah Jazirah Arab, faktor ini membuat Quraisy disegani oleh semua suku karena faktor penguasa atas simbol agama yaitu Ka'bah. Kedua, faktor ekonomi, tradisi haji yang dilaksanakan sebagai event tahunan oleh suku di sekitar Jazirah Arab membawa dampak ekonomis yang diperoleh oleh suku Quraisy. Keuntungan ekonomis yang didapat selama musim haji dikembangkan lagi oleh suku Quraisy dalam tradisi dagang pada musim dingin dan panas, sebagaimana difirmankan oleh Allah dalam al-Qur'an yang berbunyi: "iilafihim rihlatasy syita'i wa ash-shoif"'(Q.S. 106: 2). Ketiga, faktor politis, dominasi faktor agama dan ekonomi yang dimiliki suku Quraisy menjadikannya sebagai suku yang paling disegani secara politis, sehingga suku Quraisy ini memiliki dominasi politik yang tinggi dan paling ditakuti di seluruh Jazirah Arab (Wildana, Fitriani, 2008).

Perkembangan bahasa merupakan fenomena yang niscaya terjadi dalam kehidupan sosial manusia. Mengutip dari Malik (2009) masyarakat dapat melahirkan bahasa untuk berkomunikasi, masyarakat mampu menghasilkan bahasa yang beraneka ragam sesuai dengan taraf masyarakat di mana bahasa itu lahir, demikian pula bahasa dianggap sebagai makhluk hidup yang dilahirkan, hidup, berketurunan, mati, serta bersentuhan dan bersinggungan dengan Bahasa-bahasa lain. Sehingga, sesuai dengan fungsinya bangsa Arab menggunakan bahasa Arab dalam berbagai interaksi. Oleh karena itu, Bahasa Arab yang lahir di Jazirah Arab, selalu terjaga dengan baik. Selain bahasa Arab merupakan bahasa wahyu al-Qur'an yang dijanjikan oleh Allah akan selalu terjaga, sebagaimana firman Allah berbunyi: "inna nahnu nazzalna adz-dzikra wa inna lahu lahafidzun" (Q.S. 15: 9). Sebagaimana pula, selain perkembangan bahasa Arab terus terjadi secara berkelanjutan dan mengiringi peristiwa sosial kehidupan masyarakat Arab, maka proses arabisasi dan pembentukan istilah baru juga sebagai bagian dari upaya menjaga eksistensi Bahasa Arab, seperti yang terjadi dalam proses arabisasi di Kairo, Damaskus, dan Baghdad (Aziz, 2019). 


\section{METHODS}

Penelitian ini memfokuskan pada peristiwa sosial bangsa Arab yang terjadi pada masa shadr Islam yang memberikan penjelasan atas perkembangan bahasa Arab. Pemilihan fokus ini atas pertimbangan bahwa peristiwa sosial sebagai bagian terpenting yang memberikan dampak dan pengaruh atas perkembangan bahasa Arab, di mana setiap peristiwa sosial yang terjadi di kalangan bangsa Arab secara pasti melahirkan pruduksi bahasa atas reaksi kehidupan yang mereka jalankan. Dan pada masa shadr Islam, masyarakat Arab telah menjalani momentum besar yaitu masuknya Islam dan turunnya alQur'an yang disertai dengan pemahaman dan pengamalan ajaran Islam. Sehingga peristiwa ini berdampak pada interaksi yang komunikatif dengan menggunakan bahasa Arab.

Penelitian ini berupa kajian teks dan literatur yang berkenaan dengan masyarakat Arab dan perkembangan bahasa. Oleh karena itu, sumber data primer dalam penelitian ini berasal dari buku al-Mujtama'at al-Arabiyah dan buku-buku sejarah Arab dan Islam. Sehingga teknik pengumpulan data berupa dokumentasi, yaitu mengkaji teks berupa naskah yang memaparkan tentang peristiwa sosial yang terjadi pada masa shadr Islam yang memiliki pengaruh pada perkembangan Bahasa Arab.

Setelah data terkumpul, maka dipilah-pilah sesuai dengan rumusan masalah. Teknik analisa data yang dilakukan yaitu menggunakan analisa sosiologi perkembangan bahasa. Pendekatan ini dipilih karena antara peristiwa sosial yang terjadi dengan bahasa yang diproduksikan terjadi hubungan yang erat. Sebagaimana bahasa tidak muncul dari ruang hampa tanpa ada peristiwa yang melatarbelakanginya, sehingga menjadi sebab bahasa tersebut diekspresikan. Dalam sosiologi bahasa dikatakan bahwa bahasa telah berkembang karena dipengaruhi oleh peristiwa sosial yang terjadi dalam suatu masyarakat, dan struktur bahasa yang muncul merupakan refleksi budaya, sosial, politik dan ekonomi, karena bahasa merupakan media utama sebagai alat komunikasi dalam interaksi sosial masyarakat.

\section{RESULTS}

\subsection{Peristiwa-peristiwa Bersejarah dan Awal Perkembangan Bahasa Arab}

Peristiwa sosial yang terjadi pada masa shadr Islam memberikan pengaruh kuat pada peradaban bangsa Arab. Setiap peristiwa yang terjadi tidak sekedar peristiwa keagamaan biasa, tetapi peristiwa ini menjadi peristiwa sosial yang besar dan berdampak pada setiap relung-relung kehidupan. Agama Islam bermula datang di Jazirah Arabia pada abad ke-6, ketika seseorang bernama Muhammad mulai mengalami serangkaian "pewahyuan", atau komunikasi dari Ilahi. Awalnya beliau adalah Nabi yang ragu-ragu, bahkan takut kalau kenabiannya akan disangsikan orang. Namun istrinya tercinta bernama Khadijah, berkata: "Muhammad, seorang lelaki seperti kamu tidak mungkin gila." Selama lebih dari 23 tahun berikutnya, beliau menerima panduan periodik dari Sang Sumber, yang seringkali sebagai respons terhadap kebutuhan-kebutuhan tertentu umatnya yang semakin berkembang, dengan bahasa yang sangat indah dan mendalam.

Peristiwa sosial yang terjadi pada masa shadr Islam menandakan adanya proses perkembangan Bahasa Arab. Lahirnya Islam, sebagai peristiwa puncak penyampaian ajaran agama Islam telah memainkan perannya dalam proses tumbuh kembangnya Bahasa Arab. Terbukti dengan ajaran yang disampaikan oleh seorang Nabi bersumber dari pewahyuan yang disebut al-Qur'an dan menjadi inspirasi paling utama, pusat referensi, dan otoritas final dari agama Islam. Agama Islam menyampaikan ajarannya menggunakan bahasa Arab, sebagaimana dalam hal beribadah; sholat, zakat, puasa, dan ajaran yang 
lainnya diajarkan dengan menggunakan Bahasa Arab. Sehingga secara tidak langsung bahasa Arab berkembang sangat pesat. Meskipun pada awalnya mereka tidak mengerti maknanya, namun dalam peribadatan, baik pada saat berdoa, mendirikan shalat dan menyampaikan ajaran-ajaran agama, bahasa yang digunakan adalah bahasa Arab. Sehingga pada saat itu bahasa Arab adalah bahasa yang menjadi media komunikasi dan interaksi dalam kehidupan mereka.

Seiring dengan lahirnya Islam, Nabi mendapatkan perintah secara langsung dari Allah untuk menjalankan misi kenabian dengan berhijrah. Peristiwa hijrah yang pernah dijalankan oleh Nabi Muhammad SAW. terjadi sebanyak dua kali, pertama, adalah hijrah ke Habasyah dan hijrah dari Mekah ke Madinah. Kedua, peristiwa hijrah tersebut berpengaruh kuat pada perkembangan Bahasa Arab karena pada saat perpindahan bangsa Arab dari Mekah ke Habasyah dan dari Mekah ke Madinah telah berlangsung interaksi dan komunikasi di antara Nabi, sahabat dan kaum muslimin. Pada saat sebelum terjadi peristiwa hijrah, interaksi bangsa Arab hanya terbatas pada keluarga dan kabilah saja, sedangkan ketika peristiwa hijrah berlangsung, interaksi bangsa Arab menjadi semakin terbuka dan semakin meluas lintas suku dan etnis bahkan bersifat menyeluruh sesama kaum muslimin.

Dalam periodesasi sejarah, peristiwa selanjutnya yang mendorong Bahasa Arab adalah terjadinya Perang Riddah. Ketika terjadi Perang Riddah, interaksi kaum muslimin menjadi semakin luas lagi, saat itu kaum muslimin berperang memerangi suku di Yaman, Yamamah, dan Oman, karena mereka tidak mau membayar zakat. Dalam peperangan inilah terjadi interaksi sosial yang memperluas hubungan sosial umat Islam. Demikian pula terjadinya Futuhat Islamiyah (pembukaan wilayah-wilayah baru Islam) yang terjadi pasca perang Riddah, peristiwa ini terjadi di beberapa wilayah, seperti Irak, Syam, Mesir dan Maroko. Dalam peristiwa ini menjadikan tema dan topik pembicaraan kaum muslimin bangsa Arab semakin luas lagi, yang sebelumnya interaksi hanya berjalan sebatas sesama kabilah Arab. Peristiwa Futuhat Islamiyah ini mempertemukan mereka dengan banyak hal baru yang kesemuanya mendorong tumbuh kembangnya Bahasa di kalangan bangsa Arab.

Peristiwa sosial yang terjadi pada masa shadr Islam memiliki relasi yang sangat kuat pada perkembangan Bahasa Arab. Hal itu dibuktikan dengan proses arabisasi di beberapa wilayah baru pembukaan Islam, diantaranya di Irak, Syam, Mesir dan Maroko. Proses arabisasi di Irak ada dua macam yaitu: arabisasi bahasa dan arabisasi etnis. Arabisasi bahasa di Irak cenderung tidak sulit, karena di Irak terdapat penduduk Persia dan penduduk Arab, penduduk Persia menggunakan bahasa Persia dan penduduk Arab seperti para penyair, orator atau sastrawan sering menggunakan bahasa Aramia dan Samiyah yang serumpun dengan bahasa Arab, ketika di pasar atau dalam perdagangan, kedua bahasa ini (Persi dan Arab) terus menerus digunakan dan akhirnya penduduk Irak lambat laun terpengaruh dan menggunakan bahasa Arab. Proses arabisasi etnis atau bangsa dilakukan dengan tiga cara yaitu: melalui (1) as-sabiyyu (السبي) atau tawanan, (2) al-mawaliy (الموالي) atau para penguasa dan (3) melalui (الزواج) atau pernikahan. Ketiga cara tersebut bermaksud bahwa para tawanan yang mengikuti perang diharuskan memakai bahasa Arab, dalam urusan politik juga diberlakukan bagi para penguasa untuk menggunakan bahasa Arab, dan dalam pernikahan, mereka dibebaskan untuk menikah dengan siapa saja, seperti terjadinya pernikahan bangsa Arab dengan bangsa Persia. Ketiga cara dalam proses arabisasi ini lambat laun menjadikan bahasa Arab menyebarluas di kalangan masyarakat Irak.

Proses arabisasi juga terjadi di Mesir. Meskipun penduduk Mesir telah lama dijajah oleh bangsa Romawi, dan bahasa Yunani adalah Bahasa yang digunakan oleh penduduk Mesir, namun dalam percakapan sehari-hari mereka menggunakan bahasa Qibty sebagai 
ciri khas bahasa pribumi mereka atau bahasa penduduk Mesir kuno. Sehingga dalam hal ini, bahasa Arab kesulitan untuk menghegemoni bahasa mereka karena antara bahasa Arab dengan bahasa Yunani ataupun bahasa Qibty tidaklah bahasa serumpun, akhirnya dari sinilah terlahir bahasa amiyah yang tersulit sebagai wujud perlawanan bahasa setempat. Seperti yang kita kenal sekarang bahwa lahjah (dialek) yang tersulit di antara beberapa lahjah lainnya adalah lahjah Mesir. Sama hal dengan proses arabisasi di Mesir, arabisasi di Maroko juga sangat sulit karena masyarakat Maroko mengalami banyak perlawanan dari pengguna bahasa-bahasa yang berbeda. Bahasa yang digunakan oleh masyarakat Maroko sangat berbeda antara satu penduduk dengan penduduk lainnya. Seperti penduduk yang berketurunan Romawi menggunakan bahasa Yunani, maka masyarakat Maroko menggunakan bahasa Latin, Samiyah, Finiqiyah dan bahasa Barbar (Bahasa penduduk pribumi). Sejak itu, akhirnya di Maroko terlahir sebuah bahasa amiyah yang sangat sulit untuk dipahami seperti halnya bila kita menyaksikan penduduk Maroko yang bercakapcakap dengan bahasa Arab Maroko. Perbedaan bahasa antara kedua bahasa Mesir dan Maroko memunculkan peristiwa ash-Shiro' al-Lughawi (perang bahasa), karena memang Bahasa Mesir dan Bahasa Maroko tidak berasal dari satu rumpun, namun dalam peristiwa ini Bahasa Arab tetaplah menjadi bahasa yang menang, sehingga proses arabisasi di kedua wilayah ini tetaplah berjalan dengan baik.

\subsection{Faktor-faktor yang Mempengaruhi Perkembangan Bahasa Arab}

Setidaknya terdapat beberapa peristiwa sosial yang menentukan perkembangan Bahasa Arab. Tulisan ini memberikan gambaran mengenai peristiwa sosial yang terjadi pada awal shadr Islam menjadi faktor penentu perkembangan bahasa Arab.

Di antara peristiwa yang berdampak pada perkembangan bahasa Arab adalah peristiwa masuknya Islam dan turunnya al-Qur'an. Kedatangan Islam di jazirah Arab merupakan momentum agung atas masuknya ajaran Islam yang bersumber dari kitab suci al-Qur'an yang diturunkan kepada Nabi Muhammad SAW. Islam dengan kitab sucinya alQur'an tidak hanya diperuntukkan bagi segolongan kaum, namun misi yang dibawa menjadi rahmat bagi sekalian alam. Peristiwa datangnya Islam dengan al-Qur'an yang agung ini menjadi keistimewaan bagi bangsa Arab yang mampu menumbuhkembangkan bahasa Arab di kalangan mereka. Masuknya Islam dan turunnya al-Qur'an, meningkatkan gairah perbincangan yang terjadi di kalangan bangsa Arab menjadi semakin beragam dan menembus batas lintas wilayah dan kabilah.

Sebagaimana yang terjadi pada peristiwa masuknya Islam dan turunnya al-Qur'an, maka penyampaian ajaran Islam yang dimulai dari bangsa Arab kemudian meluas ke beberapa wilayah di luar Arab meniscayakan hubungan komunikasi dan interaksi sosial antar berbagai etnis dan bangsa dapat terbangun dengan baik. Interaksi sosial yang dibangun oleh Islam melalui peristiwa hijrah, peperangan dan penaklukan wilayah baru Islam melahirkan soliditas dan solidaritas umat Islam di kalangan bangsa Arab dan sekitarnya. Soliditas dan solidaritas umat Islam ini memudahkan penyampaian ajaran Islam dan menggerakkan motivasi serta semangat baru bagi umat Islam dalam memahami dan mengamalkan ajaran Islam. Hal ini memberikan pengaruh bagi bahasa Arab sehingga semakin tumbuh dan berkembang pesat, keluar dari batas topik perbincangan yang terjadi pada masa pra Islam.

Pada masa pra Islam, tradisi jahiliah kurang mendukung berkembangnya sebuah bahasa. Interaksi yang terbatas antara sesama anggota kabilah, membuat bahasa Arab miskin perbendaharaan kata, tema-tema perbincangan bangsa Arab terbatas pada lingkungan yang sangat sempit. Namun, setelah kedatangan Islam, peristiwa ini tidak sekedar menjadi peristiwa keagamaan an sich, akan tetapi Islam justru menciptakan 
revolusi perkembangan bahasa Arab yang luar biasa. Tema-tema baru muncul dengan sangat beragam, mulai dari ritual keagamaan, prinsip-prinsip keimanan, etika dalam Islam, sebagaimana pula saat itu juga dikembangkan keilmuan Islam seperti materi fiqih muamalah, fiqh ibadah, fiqih munakahat jinayat, fiqih zakat dan keilmuan lain yang tumbuh dan berkembang berdasarkan sumber dari agama Islam.

Perkembangan bahasa Arab juga dipengaruhi oleh adanya dominasi bahasa Arab atas bahasa lain. Dengan adanya ajaran Islam yang mengajarkan berbagai keilmuan baru di negeri Arab, secara tidak langsung menunjukkan adanya perkembangan bahasa Arab. Setiap pengetahuan yang disampaikan kepada bangsa Arab tidak lepas dari bahasa pengantar yang menjelaskan dan memberikan pemahaman ajaran agama Islam. Bahasa Arab memainkan peran penting sebagai media dalam penyampaian keilmuan baru dalam Islam. Tidak hanya substansi yang disampaikan saja, melainkan tatacara praktik-praktik keagamaan menggunakan bahasa Arab, demikianlah ajaran Islam diajarkan secara langsung oleh Nabi Muhammad SAW.

Sebagai bahasa yang komunikatif di kalangan umat Islam, maka bahasa Arab menduduki posisi penting dalam praktek segala aspek kehidupan umat Islam. Seperti peristiwa penaklukan wilayah baru Islam ke beberapa negara di sekitar jazirah Arab. Peristiwa yang dikenal dengan istilah futuhat islamiyah ini merupakan peristiwa yang memberikan keuntungan tersendiri bagi perkembangan Bahasa Arab. Selain kedekatan wilayah penaklukan dalam penyebarluasan ajaran Islam, kedekatan rumpun Bahasa yang melekat pada masing-masing pengguna Bahasa di wilayah tersebut menunjukkan kemudahan dan cepatnya perkembangan Bahasa Arab. Sebagai gambaran yaitu rumpun bahasa Semit yang tersebar di sepanjang wilayah Syam, Irak dan bahkan sebagian Afrika Utara. Antara bahasa Hijaz dan bahasa Arab di Irak memiliki hubungan kedekatan, bahkan mereka menyebut bahasa Arab Hijaz dengan sebutan Arab Jazirah dan bahasa Arab Irak disebut dengan Arab Dhohiyah.

\subsection{Model Perkembangan Bahasa Arab yang Terbentuk dari Peristiwa Sosial pada Masa Shadr Islam}

Peristiwa sosial yang terjadi di kalangan bangsa Arab tidak sekedar memberikan dampak dan pengaruh atas perkembangan bahasa Arab. Peristiwa-peristiwa ini juga menunjukkan adanya model efektif dalam proses perkembangan bahasa. Sebagaimana peristiwa datangnya Islam yang membawa ajaran mulia bertujuan membangun tata sosial bagi umat Islam. Nabi Muhammad datang di hadapan kaum jahiliyah dengan membawa empat prinsip yaitu: prinsip ruhaniyah, prinsip sosial, prinsip kemanusiaan, dan prinsip rasionalitas telah merubah tradisi dan pola kehidupan yang terbelakang menuju kepada kehidupan yang berperadaban. Sehingga, yang sebelumnya mereka hidup dengan berkelompok-kelompok kemudian mereka beralih menuju kehidupan yang dijalankan secara bersama-sama dan saling membantu satu sama lainnya. Kedatangan Islam menjadikan revolusi yang sangat berpengaruh bagi orang Arab dan Bahasa mereka. Sebagaimana ajaran Islam mengajarkan perihal tatacara beribadah, ajaran tersebut diajarkan dengan menggunakan bahasa Arab, dan secara tidak langsung bahasa Arab berkembang sangat pesat. Meskipun pada awalnya mereka tidak mengerti maknanya. Namun dalam peribadatan, baik berdoa, mendirikan shalat, menyampaikan ajaran-ajaran agama, bahasa yang digunakan adalah bahasa Arab. Sehingga pada saat itu bahasa Arab adalah bahasa ibadah, dan media komunikasi dalam kehidupan mereka.

Ajaran agama yang disampaikan oleh Nabi Muhammad SAW. juga menegaskan bahwa misi kenabian yang dijalankan oleh Nabi Muhammad SAW. ini berlaku bagi seluruh umat dan disebarluaskan ke seluruh umat di alam semesta. Dalam peristiwa 
penyebarluasan risalah Islam ini telah terjadi adanya pertemuan kaum muslimin dengan kaum muslimin lainnya, sikap mereka menjadi lebih terbuka dan lebih luas. Ketika Nabi dan kaum muslimin dipertemukan dengan kaum muslimin yang berasal dari berbagai wilayah maka terdapat model interaksi yang dimunculkan. Pertemuan kaum muslimin inilah yang akhirnya menjadi model yang sangat efektif atas perkembangan Bahasa Arab yang terus berkelanjutan dan berkesinambungan.

Uraian di atas memperlihatkan bahwa setiap peristiwa sosial yang dijalani bangsa Arab pada awal masa shadr Islam memiliki korelasi yang sangat kuat pada perkembangan bahasa Arab.

\section{DISCUSSION}

\subsection{From Jahiliyah Era to Shadr Islam Era}

Kehidupan bangsa Arab pada masa jahiliyah merupakan kehidupan yang bersifat kesukuan/kabilaisme (tribe). Sistem kabilah yang dianut oleh bangsa Arab menciptakan pola kehidupan yang selalu bersaing antar suku dan kabilah, enggan menerima nasehat, enggan bersosial dengan selain kabilahnya dan sering terjadi peperangan antar suku dan kabilah. Pola kehidupan yang demikian telah mencitrakan bangsa Arab di masa jahiliyah sebagai bangsa yang primitif, tidak berperadaban, dan tidak berinteraksi lintas kabilah. Di pihak lain, bangsa Arab menjalankan hidup secara bersuku-suku dan berkabilah karena kehidupan mereka berada di padang pasir, selain juga mereka merupakan pengembara yang mencari oase-oase sebagai sumber kehidupan di padang pasir. Maka secara sosial, kehidupan mereka secara berkabilah merupakan salah satu cara untuk bertahan hidup di tengah persaingan hidup bersama kabilah-kabilah lain. Sartre menegaskan bahwa kondisi kehidupan bangsa Arab secara berkabilah memiliki peran penting dan sangat menentukan kekuatan mereka (Sartre, 2005). Selain pertimbangan psikologis, kehidupan kabilaisme juga didasarkan pada ciri kehidupan bangsa primitif yang sering berperang.

Pola hidup primitif yang monoton dan cenderung bersikap eksklusif, menjadikan bangsa Arab di masa Jahiliyah tidak mampu mengembangkan daya kreativitasnya dalam berbahasa. Bahasa Arab pada masa jahiliyah hanya berputar pada kehidupan kabilah yang terbatas, tema yang sederhana dan kosakata yang terbatas pula. Ungkapan dan perbincangan juga sangat terbatas pada interaksi dan peristiwa sosial yang mereka jalani di tingkat kabilah dan sukunya saja, sementara itu potensi manusia untuk berbahasa sejatinya akan bisa diwujudkan jika lingkungan sosial sudah mereka dapatkan dan mereka wujudkan (Hoff, 2006). Sedangkan bangsa Arab pada masa Jahiliyah memiliki kecenderungan fanatik terhadap golongan dan kabilah masing-masing yang mengakibatkan adanya lingkup lingkungan sosial cenderung terbatas dan sempit.

Keterbatasan dan sempitnya lingkungan sosial bangsa Arab ini mengakibatkan lambatnya perkembangan bahasa, baik kosakata, diksi maupun tema perbincangan. Perkembangan bahasa yang terjadi secara lambat sesungguhnya tidak memberikan dampak positif, namun justru mengarah pada kondisi yang menghambat peradaban dan kemajuan. Sejalan dengan pernyataan Rodríguez (2006) yang mengungkapkan bahwa penguatan multibahasa dalam masyarakat menjadi unsur terpenting dalam membangun peradaban, maka multibahasa pada masyarakat lebih memungkinkan terwujudnya pluralisme linguistik secara sosial dan berfungsi secara baik untuk mempertahankan kualitas lembaga atau insitusi suatu bangsa. Di samping juga, keragaman bahasa mampu memastikan kokohnya dan kuatnya masyarakat yang multietnis, karena setiap individu yang kokoh secara bahasa akan mampu meningkatkan akses ke lembaga-lembaga sosial penunjang kehidupan mereka. 


\subsection{Perkembangan Bahasa Arab: Pengaruh Peristiwa Sosial Pada Masa Shadr Islam}

Peristiwa sosial yang terjadi di kalangan bangsa Arab khususnya pada masa awal shadr Islam menjadi tanda tumbuh dan berkembangnya Bahasa Arab. Bahasa Arab yang lahir di Jazirah Arab tidak akan mengalami perkembangan yang signifikan jika tidak ada peradaban yang berkembang di kalangan bangsa Arab. Peristiwa sosial yang terjadi di kalangan kaum muslimin menjadi faktor penentu perkembangan Bahasa Arab. Kehadiran Islam di kalangan bangsa Arab mendobrak fanatisme bangsa Arab atas sempitnya pergaulan dan interaksi mereka bersama kabilahnya. Modernisasi peradaban dan ajaran yang dibawa oleh Islam menjadikan bangsa Arab mampu berkomunikasi dan berinteraksi dengan bangsa lain yang lebih luas di luar jazirah Arab. Luasnya interaksi dan komunikasi yang dijalankan oleh kaum muslimin mempertemukan mereka dengan berbagai etnis dan bangsa lain, yang dulunya tidak pernah mereka jalankan pada saat mereka berada pada masa jahiliyah.

Pergeseran peradaban yang diorganisir oleh Islam melalui ajarannya yang sangat mulia berakibat positif pada perkembangan Bahasa Arab. Dalam interaksi dan komunikasi yang dijalankan meniscayakan kaum muslimin bereksplorasi dalam meluaskan topik dan tema perbincangan mereka. Dalam memperbincangkan topik yang beragam ini, bangsa Arab secara umum menggunakan dialek Quraisy. Dialek Quraisy merupakan dialek yang mendominasi di antara dialek-dialek kabilah Arab lainnya. Selain dialek Quraisy juga merupakan dialek yang mudah dipahami dan diterima oleh bangsa Arab.

Keterbukaan bangsa Arab atas penerimaan ajaran Islam menjadi faktor penentu perkembangan bahasa Arab. Hal itu menunjukkan bahwa bahasa yang dipakai dalam ajaran agama dan al-Qur'an menjadi media yang memberikan gairah untuk digunakan dalam komunikasi dan perbincangan sehari-hari dan dalam menjalani setiap peristiwa sosial dalam kehidupan mereka. Model berbahasa bangsa Arab pada masa ini menggeser gaya berbahasa mereka yang sebelumnya cenderung menggunakan dialek kabilah-kabilah, peristiwa ini sejalan dengan pernyataan Irwan yang menyatakan bahwa proses stylization dalam berbahasa sangat mungkin terjadi, senada dengan maksud dari stylization merupakan gaya dalam berbahasa yang jauh lebih dominan dibandingkan aturan normatif dalam penggunaan bahasa (Irwan, 2006). Maka sejak lahirnya Islam, style berbahasa bangsa Arab yang berubah dari dialek menuju bahasa menjadi cirikhas bangsa Arab seiring dengan peristiwa pemahaman dan pengamalan ajaran Islam di kalangan mereka.

\subsection{Peristiwa Sosial yang terjadi pada Masa Shadr Islam Berdampak Pada Perkembangan Bahasa Arab.}

Islam yang turun di kalangan bangsa Arab telah menjadikan bangsa Arab mengalami transformasi luar biasa dalam berbahasa. Seiring dengan ajaran Islam yang diturunkan kepada mereka, mereka dipersatukan dengan bahasa Arab fusha, yaitu bahasa agama dan bahasa al-Qur'an. Sentuhan agama yang menjadi kebutuhan mereka telah memperkaya kosakata dan perbendaharaan bahasa mereka. Kecenderungan ini merupakan proses transformasi besar-besaran yang dialami oleh bangsa Arab, yang sebelumnya mereka hanya memiliki kecenderungan fanatisme terhadap bahasa kabilah masing-masing. Transformasi bahasa ini mampu mendobrak kelemahan dialek setiap kabilah yang ada. Kelemahan dan kurangnya penggunaan bahasa kabilah Arab, menyebabkan lemahnya fungsi kontrol bahasa kabilah, selain karena kredibilitas bahasa yang berkurang, maka penggunaan bahasa kabilah (dialek) tidak lagi efektif untuk 
komunikasi antar kabilah di kalangan bangsa Arab. Masuknya Islam kepada bangsa Arab mampu menguatkan eksistensi bangsa Arab, karena seiring turunnya Islam, ajaran Islam juga mampu memperluas kajian dan tema perbincangan di kalangan mereka.

Selain peristiwa turunnya Islam, bangsa Arab telah mengalami peperangan yang bertujuan untuk mengembalikan ajaran Islam ke hadapan kaum muslimin. Peristiwa peperangan di kalangan umat Islam juga berfungsi sebagai laboratorium Bahasa yang bersifat alamiyah, bukan buatan, dan terjadi tanpa ada rekayasa dalam proses berbahasa. Dari peristiwa perang yang terjadi pada masa shadr Islam, secara alamiah kaum muslimin melahirkan berbagai macam kosakata dan perbendaharaan kata dalam bahasa Arab, yang kemudian terbakukan menjadi bahasa komunikasi di kalangan mereka. Persatuan dan kesatuan yang terbangun di kalangan bangsa Arab juga mampu diwujudkan, hal ini telah mampu menggeser fungsi bahasa (dialek) kabilah kemudian beralih kepada bahasa umat Islam. Sehingga bahasa Arab fusha yang tumbuh dan berkembang saat itu melegitimasi bahasa Arab ini terus berjalan seiring dengan disebarkannya ajaran agama di kalangan bangsa Arab dan mengokohkan eksistensi umat Islam di kalangan bangsa Arab..

Dengan demikian, peristiwa sosial yang terjadi telah mengiringi perkembangan bahasa Arab, juga terus mereproduksi bahasa menjadi lebih baik, dan ajaran agama yang disampaikan pun turut merevitalisasi peran bahasa Arab di kalangan bangsa Arab.

\section{CONCLUSION}

Peristiwa sosial yang terjadi pada masa shadr Islam berdampak pada perkembangan bahasa Arab. Bangsa Arab yang semula merupakan bangsa primitif, menganut sistem kabilaisme, fanatisme terhadap suku dan kabilahnya telah mengalami transformasi peradaban yang sangat pesat sejak lahirnya Islam, hal ini turut mengantarkan mereka menuju bangsa yang berperadaban. Majunya peradaban yang terjadi turut mengantarkan bangsa Arab dalam merevitalisasi bahasa Arab dalam setiap interaksi dan komunikasi yang mereka jalankan. Interaksi dan komunikasi ini melahirkan kekayaan kosakata, perbendaharaan kata dan menambah tema-tema perbincangan, sementara pada sebelumnya penggunaan bahasa hanya terbatas pada bahasa kabilahnya saja. Peristiwa sosial yang terjadi pada masa shadr, yang dimulai dari sejak lahirnya Islam, peristiwa hijrah, perang Riddah telah memberikan penegasan atas dampak positif terhadap perkembangan bahasa Arab. Hal ini menjadi bukti atas pencapaian bangsa Arab dalam menumbuhkembangkan bahasa Arab sebagai bahasa pemersatu di jazirah Arabia.

Perkembangan bahasa tidak mungkin dapat berlangsung dengan baik jika kabilah tetap mempertahankan kehidupan yang sektarian dan kabilaisme. Islam dengan peristiwa agung telah datang dengan ajarannya yang sangat mulia, membuka cakrawala pengetahuan bagi bangsa Arab, selain juga Islam membawa ajaran agama dengan bahasa yang sangat santun, bijaksana dan mudah untuk dimengerti dan diamalkan. Motivasi positif juga telah diberikan kepada bangsa Arab melalui peristiwa lahirnya Islam, peristiwa hijrah, perang Riddah dan futuhat Islamiyah, bahwa hubungan interaksi dan komunikasi tidak lagi terbatas dan sempit dalam lingkup kabilahnya saja, akan tetapi interaksi dan komunikasi menjadi lebih luas bersama kaum muslimin secara umum. Sehingga hubungan sosial, tema perbincangan menjadi semakin berkembang keluar tanpa ada batas dan sekat-sekat kabilah.

Tulisan ini menunjukkan hasil bahwa peristiwa sosial yang dijalani bangsa Arab merupakan transformasi dan kontekstualisasi tradisi bangsa Arab dari sistem kabilah ekslusif menuju sistem persatuan sesama kaum muslimin yang terbuka dan inklusif. Peristiwa sosial yang terjadi di kalangan bangsa Arab mampu menjawab kebuntuan bangsa Arab dari sulit dan sempitnya berinteraksi dan berkomunikasi, kemudian 
mengarahkan pada keterbukaan dan pencapaian perkembangan peradaban yang gemilang. Studi ini meskipun hanya memperhatikan pada aspek peristiwa sosial pada masa shadr Islam yang berdampak pada perkembangan bahasa Arab, namun tidak menafikan peristiwa berikutnya yang memiliki pengaruh pada perkembangan bahasa Arab. Peristiwa sosial lainnya yang bergulir dalam kehidupan manusia masih membutuhkan kajian lebih lanjut untuk menemukan style dan model transformasi dalam proses perkembangan bahasa.

\section{References}

Ahmad, K., \& Azzam, S. (2010). Islam: Its Meaning and Message. In The Islamic Foundation.

Ali, A. J. (1995). Cultural Discontinuity and Arab Management Thought. International Studies of Management \& Organization. https://doi.org/10.1080/00208825.1995.11656657

Bin Tahir, S. Z. (2017). Multilingual teaching and learning at Pesantren Schools in Indonesia. Asian EFL Journal, 89, 74-94.

Bin Tahir, S. Z. (2015). Multilingual behavior of Pesantren IMMIM students in Makassar. Asian EFL Journal, 86, 45-64.

Bin-Tahir, S. Z., \& Rinantanti, Y. (2016). Multilingual lecturers' competence in english teaching at the university of Iqra Buru, Indonesia. Asian EFL Journal, 5, 79-92.

bin Tahir, Z. Saidna, 2015. The Attitude of Santri and Ustadz Toward Multilingual Education in Pesantren. International Journal of Language and Linguistics, 3(4).

Bin-Tahir, S. Z., Bugis, R., \& Tasiana, R. (2017). Intercultural Communication of a Multicultural Family in Buru Regency. Lingual: Journal of Language and Culture, 4(2), 8-8.

Saidna Z, B. T., Haryanto, A., Syarifuddin, D., \& Yulini, R. (2017). Multilingual Instructional Model of Pesantren Schools in Indonesia. Journal of Language Teaching and Research, 8(6), 1210-1216.

Tahir, S. Z. A. (2015). Improving Students' Speaking Skill through Yahoo Messenger at University of Iqra Buru. International Journal of Language and Linguistics, 3(3), 174-181.

Bin Tahir, S. Z. (2015). Multilingual Education in Pesantren Context. Yogyakarta: Deepublish.

Bin-Tahir, S. Z., Atmowardoyo, H., Dollah, S., \& Rinantanti, Y. (2017). Multilingual learning program: pesantren students' perceptions of the multilingual simultaneoussequential model. JELE (Journal Of English Language and Education), 3(2), 44-53.

bin Tahir, S. Z. (2012). Teaching English as World Language: Pengajaran Bahasa Inggris. Media Pustaka Qalam.

Bin-Tahir, S. Z. (2010). English Teaching Methods at Pesantren IMMIM of Makassar.

bin Tahir, S. Z. (2015). Students' Speaking Skill through Voice Chat at University of Iqra Buru. Journal of Modern Education Review, 5(3), 296-306.

Tahir, S. Z. B. (2015). Multilingual Teaching And Learning At Pesantren. 14 Asian EFL Journal Conference.

Bin Tahir, S. Z. (2013). Pengajaran Bahasa Inggris-Teaching English as World Language. Jakarta: Media Pustaka Qalam.

Tahir, S. Z. (2012). Redefining Terms of Teaching and Learning Strategy Methods, Approach, Technique, and Models. English Department of the University of Iqra Buru. 
bin Tahir, S. Z. (2010). Modal Dasar Menguasai Bahasa Inggris: A Stepping Stone Toward Mastering English Grammar. Media Pustaka Qalam.

Bin-Tahir, S. Z. (2015). The Power of Love: The Role of Boyfriend in English Language Acquisition.

Tahir, S. Z. B., \& Buru, D. U. I. (2012). Humor in "Bukan Empat Mata" Talk Show. Jurnal JUPITER, 5(4), 68-74.

Zulfiqar, S. (2013). Teaching Speaking through Yahoo Messenger. Jakarta: Media Pustaka Qalam.

Bin Tahir, S. Z. (2013). Penggunaan Facebook Untuk Meningkatkan Kemampuan Menulis Teks Deskriptif Mahasiswa Fkip Jurusan Bahasa Inggris Di Universitas Iqra Buru. Jurnal Prospek, 15(1), 68-76.

TAHIR, S. Z. B. TEACHING SPEAKING THROUGH YAHOO MESSENGER.

Tamimi Arab, P. (2018). What is Islam? The importance of being Islamic. Material Religion. https://doi.org/10.1080/17432200.2017.1418224

Wildana, W., \& Fitriani, L. (2008). "Sastra Arab dan Lintas Budaya." In UIN-Malang Press. 